\author{
V. I. Gulik', V. M. Pavlovych ${ }^{2}$ \\ ${ }^{1}$ Institute for Safety Problems of Nuclear Power Plants, NAS of Ukraine, 12, Lysogirska st., Kyiv, 03028, Ukraine \\ ${ }^{2}$ Institute for Nuclear Research of NAS, 47, Nauky av., Kyiv, 03680, Ukraine
}

\title{
The Development of Neutron-Physical Model for Two-Zone Research Subcritical Reactor for Nuclear Waste Transmutation
}

Keywords:

Accelerator Driven Systems, subcritical system, transmutation of nuclear waste, optimization of subcritical core.

\begin{abstract}
The creation of small-scale research subcritical reactors is necessary, in particular, for the development of the technology for nuclear waste transmutation in Accelerator Driven Systems. The construction of such facilities will allow the development of the technology of nuclear waste transmutation without constructing an expensive industrial scale subcritical reactor. The low-cost neutron generator can serve as a driver for such research subcritical reactors. A two-zone model of subcritical system driven by high-intensity neutron generator is proposed in this work. The proposed system can use two separated cores with different neutron spectra: fast and thermal. This paper also represents the main stages of the proposed model of two-zone subcritical reactor development. The results of simulations, aimed at optimizing of the geometry and fuel composition of the two-zone subcritical system, performed in Serpent and MCNP codes are presented. An overview of the analysis of different facilities that can be used as an external neutron source for subcritical reactor is shown, however a high-intensity neutron generator based on $\mathrm{D}$ - $\mathrm{T}$ reaction was chosen as the optimal neutron source for low-cost research subcritical reactor for investigation of nuclear waste transmutation. Generally, it is observed that the two-zone subcritical system can effectively amplify neutron flux from external neutron sources.
\end{abstract}

\section{Introduction}

After Three Mile Island accident in the United States (1979), the Chornobyl disaster in Ukraine (1986) and Fukushima Daiichi disaster in Japan (2011), the safe operation of nuclear reactors has become a very controversial topic. Since the mid-twentieth century the huge quantity of spent nuclear fuel and vitrified nuclear waste obtained by the operation of conventional nuclear reactors has been accumulated. Currently, many countries have still not implemented a strategy for dealing with spent nuclear fuel and nuclear waste management. On the other hand, there are also some countries (such as Sweden and Finland) which adopted a strategy for the final disposition of spent nuclear fuel in deep geological repositories, but so far there is no existing storage of spent nuclear fuel or nuclear waste for a long-term period with the exception of the experimental facility in Sweden.

Over the past twenty years the possibility of solving nuclear waste problem by means of nuclear waste transmutation has been heavily investigated [1-3]. The nuclear waste can be divided into two main categories: minor actinides and long-lived fission products [4]. The minor actinides include isotopes such as: ${ }^{237} \mathrm{~Np},{ }^{241} \mathrm{Am},{ }^{243} \mathrm{Am}$, ${ }^{244} \mathrm{Cm}$ etc. The transmutation of minor actinides occurs mainly as a result of fission reaction. As shown in number studies, the most favorable conditions for minor actinides transmutation are observed in fast neutron spectrum [5]. Therefore, the fast reactors or the subcritical systems driven by an external neutron source with sufficiently high neutron energy (Accelerator Driven Systems (ADS)) are considered to be the most realistic scheme

(C) V. I. Gulik, V. N. Pavlovych, 2019 
for minor actinides transmutation. On the other hand, the long-lived fission products include some of the following isotopes: ${ }^{129} \mathrm{I},{ }^{99} \mathrm{Tc},{ }^{99} \mathrm{Zr},{ }^{135} \mathrm{Cs},{ }^{126} \mathrm{Sn}$ etc. The long-lived fission products transmutation occurs mainly as a result of capture reaction. It has been found in several studies that the most favorable conditions for transmutation of long-lived fission products are observed in the thermal neutron spectrum $[6,7]$. However, the transmutation of long-lived fission products in the traditional critical reactors is complicated due to a number of technical issues. Therefore, the subcritical systems with thermal neutron spectrum are a great option to investigate long-lived fission products transmutation.

The development of neutron-physical model of twozone research subcritical reactor driven by high-intensity neutron generator for investigations of minor actinides and long-lived fission products transmutation has been described in the present paper.

\section{Model development}

\section{High-intensity D-T neutron generator as a driver for subcritical core}

The analysis of the latest research of subcritical systems driven by external neutron source (Fig. 1) helps to summarize what type of facilities of external neutron source could be used:

1. The proton (cyclotron or linear) accelerator that uses spallation reactions to produce neutron flux in the subcritical reactor [8]. Advantage: high intensity of neutron source; disadvantages: high cost and difficulties in beam-window construction. MYRRHA project in the European Union [9] can be given as an example to this type of facility.

2. Electron accelerators that use photon-neutron reactions to produce neutron flux in the subcritical reactor [10]. Advantage: the possibility to obtain sufficiently high current of electrons and therefore the relatively high intensity of neutron source; disadvantage: high cost. An example of this type of facility is the KIPT neutron source facility in Kharkiv, Ukraine [11].

3. High-intensity neutron generator and plasma focusing (PF) devices that use deuterium-tritium (D-T) reactions to produce neutron flux in the subcritical reactor [12-14]. Advantages: relatively low cost and well-known technology; disadvantages: relatively low intensity of neutron source and necessity to have tritium producing facility. A good example is the YALINA-booster facility in Belarus [15].

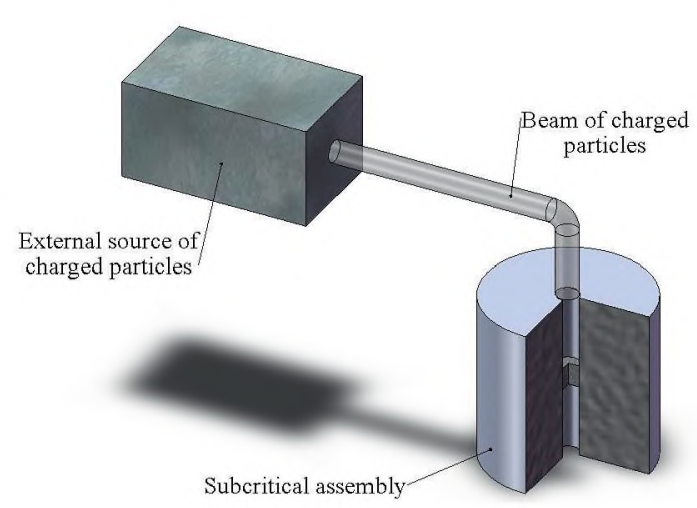

Fig. 1. Simple scheme of ADS

4. Fusion neutron sources based on the fusion reaction to produce neutrons in the subcritical reactor [16]. Advantage: high intensity of neutron source; disadvantages: still under development, so not ready for immediate use.

In the condition of limiting funds, such as in Ukraine at present time, it is impossible to develop and construct the expensive high current proton and electron accelerators, so the option of D-T neutron source is an optimal solution for the development of experimental facilities for the investigation of nuclear waste transmutation in such cases.

Another useful feature of the proposed subcritical reactor is the existence of two cores with different neutron spectra in a single facility (fast and thermal). There are two major advantages in such a two-zone subcritical system: 1) the ability of more effectively enhancing the neutron flux from the external source [17]; 2) the fact that it is very convenient to investigate transmutation of minor actinides and long-lived fission products, due to the existence of fast and thermal neutron spectra in a single facility $[5,6]$.

\section{The using of MCNP Monte Carlo code for model development}

The investigations of two-zone subcritical system driven by high-intensity neutron generator were performed in Institute for Nuclear Research in Kyiv, Ukraine, whose scientists had a big experience in high intensity neutron generators design and production [18], as well as in study of neutron flux amplification in subcritical assemblies of different types and different material composition [19-22]. The neutron and energy amplification factor were selected as basic parameters for this study. 
The neutron codes MCNP-4c and SCALE-5 as well as ENDF/B-VI nuclear data library were used for the simulation stage [23].

Thereafter, the research of amplifying abilities of two-zone subcritical system, geometrical optimization and optimization of material composition of such systems were performed [24-27]. It has been found that two-zone subcritical system can more effectively amplify the neutron flux from external source than one-zone subcritical system, from the point of view of neutron economy. The optimal geometric and material characteristics for inner and outer zones of subcritical reactor also were established.

Nuclear waste transmutation was simulated using codes MCNP, ORIGEN and Monteburns for developed MCNP model of two-zone subcritical reactor. The transmutation of main minor actinides in the inner zone with fast neutron spectrum was carried out along with the transmutation of main long-lived fission products in the outer zone with thermal neutron spectrum. The main results for the modeling of nuclear waste transmutation were presented in our previous publications $[28,29]$.

The diagram of the final version of MCNP code model is presented in Fig. 2. The overall conditions for the present MCNP model were:

1) geometry and material parameters of fuel elements for VVER-1000 reactor;

2) the fuel in pins - uranium dioxide with different enrichments for ${ }^{235} \mathrm{U}$ (in inner zone - $15 \%$, in outer zone $-4 \%$ );

3) fuel density - $10.96 \mathrm{~g} / \mathrm{cm}^{3}$;

4) cladding material - zirconium $+1 \%$ niobium;

5) hexagonal lattice of fuel elements was used in both zones;

6) coolant of inner zone is helium whereas coolant of outer zone is light water;

7) the effective neutron multiplication factor is 0.97. The ENDF/B-VI nuclear reaction database containing evaluated (recommended) cross sections was also used for MCNP calculations.

In addition, there are also MCNP visualizations for the developed two-zone subcritical model which are presented in Figs. 3-6.

\section{Serpent Monte Carlo code for model development}

The second stage of the presented work was the model development of the two-zone research subcritical reactor driven by high-intensity neutron generator

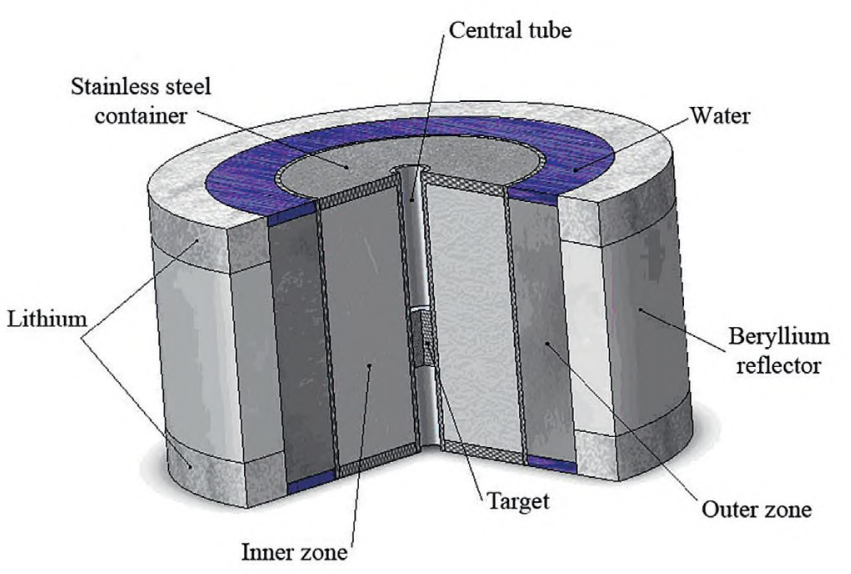

Fig. 2. Diagram of the two-zone subcritical reactor model developed by MCNP code

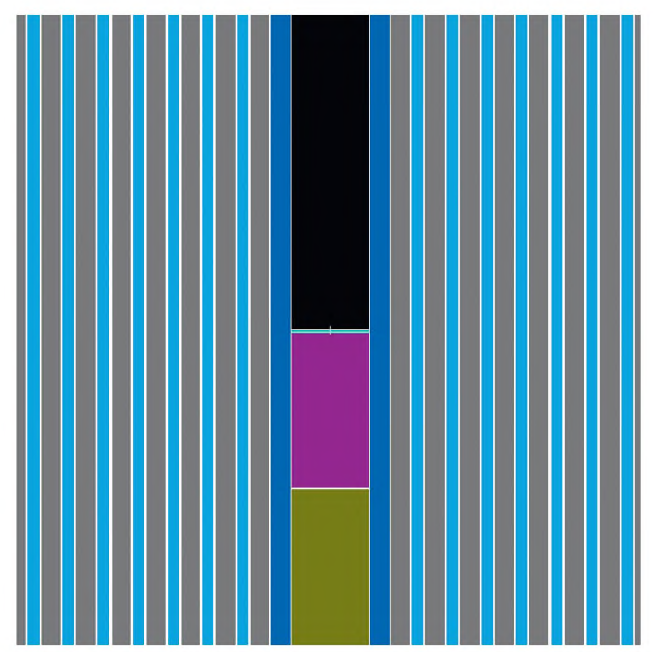

Fig. 3. Vertical cross-section view of central part for calculated model in MCNP code

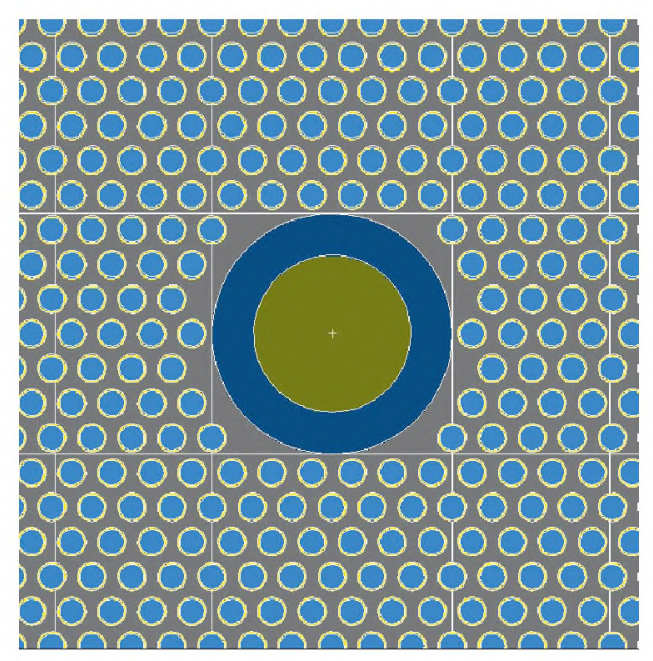

Fig. 4. Horizontal cross-section view of central part for calculated model in MCNP code 


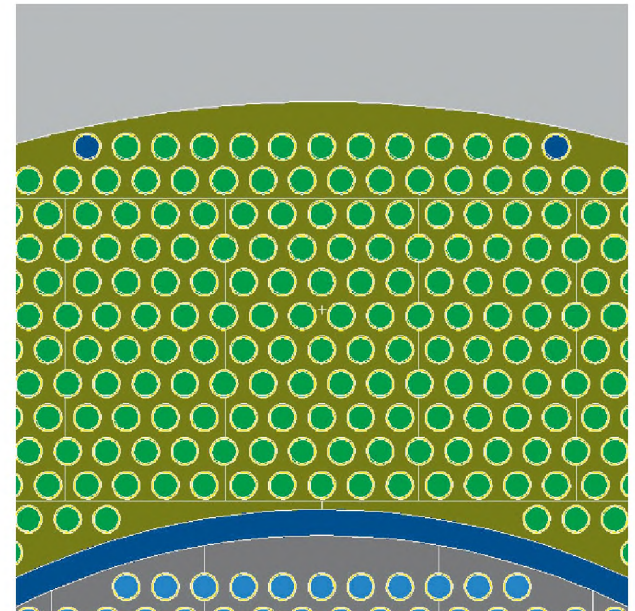

Fig. 5. Horizontal cross-section view of outer zone for the calculated model in MCNP code

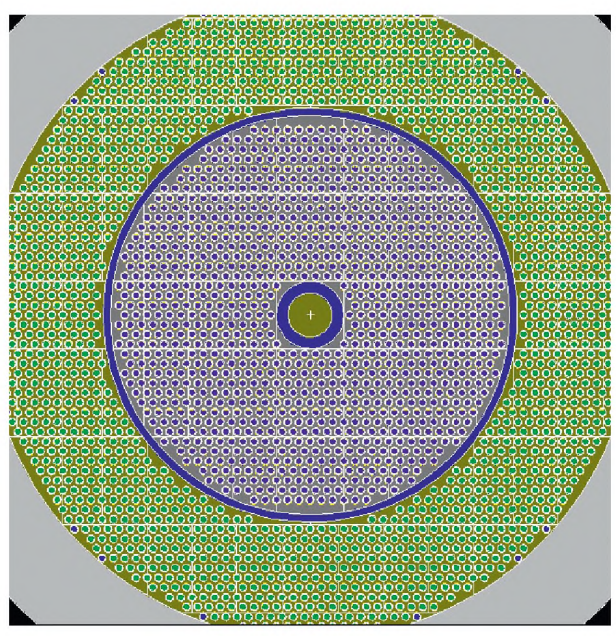

Fig. 6. Horizontal cross-section view of the whole core for the calculated model in MCNP code

using new Monte Carlo Serpent code [30]. Serpent code has been developed in Finland in VTT Technical Research Centre since 2004. There are two main advantages of studying the subcritical systems in Serpent Monte Carlo code: i) the possibility of modeling of a subcritical system with external neutron source and ii) the possibility of burnup calculation for the simulation of nuclear waste transmutation.

The first modelling results of the two-zone subcritical system with uranium dioxide for homogeneous case with the help of the Serpent code were presented in our previous publication [31]. Additional calculation results of the modelled homogeneous subcritical system with uranium metallic fuel without coolant and cladding materials are also presented in this paper. The diagram of the final version of Serpent code model is shown in
Fig. 7 and visualization Serpent code is displayed in Fig. 8. The typical conditions for the present Serpent model were: 1) homogenizing fuel - uranium metallic with different enrichments for ${ }^{235} \mathrm{U}$ (in inner zone $20 \%$, in outer zone $-4 \%$ ); 2) fuel density $-19.07 \mathrm{~g} / \mathrm{cm}^{3}$; 3) effective neutron multiplication factor set to 0.97. The ENDF/B-VII nuclear data library was used for Serpent calculations.

The optimization results of the two-zone subcritical system with heterogeneous fuel were presented in our previous work [32] with the help of Serpent simulation.

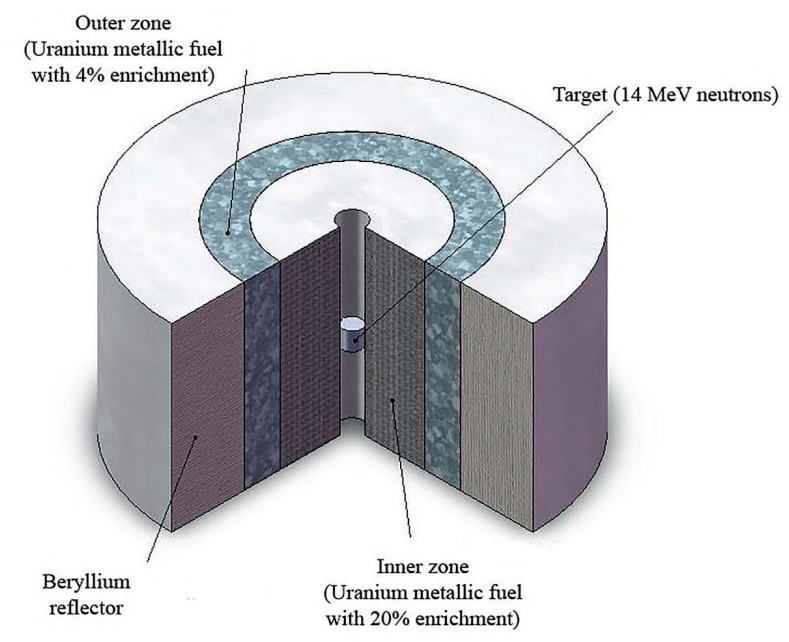

Fig. 7. Diagram of the two-zone subcritical reactor model for homogeneous systems

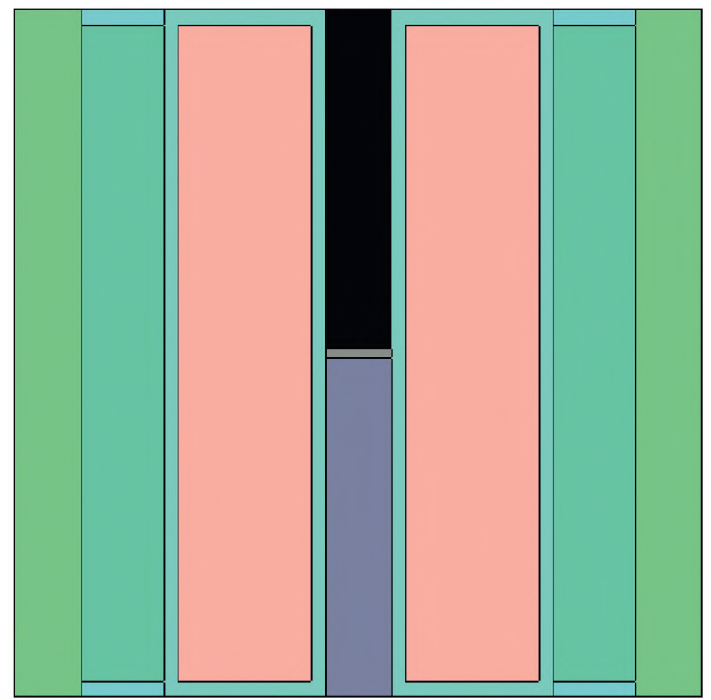

Fig. 8. The scheme of the calculated homogeneous model in Serpent code 


\section{MCNP and Serpent modelling results}

\section{The modelling of transmutation characteristics for two-zone subcritical system}

Homogeneous mixture of uranium metallic enriched in ${ }^{235} \mathrm{U}$ for $20 \%$ in the inner zone and a homogeneous mixture of uranium metallic with $4 \%$ enrichment in ${ }^{235} \mathrm{U}$ in the outer zone were considered as fuel material in the present model. Zones have neither coolant nor cladding materials, therefore both zones have fast neutron spectrum in neutron-physical model. Other characteristics for this case are presented in section 2.3. The Serpent code was used for this modelling.

The following are some of the additional parameters in the developed model:

diameter of the target is $5 \mathrm{~cm}$;

thickness of stainless steel container wall is $1 \mathrm{~cm}$;

thickness of the beryllium reflector is $5 \mathrm{~cm}$;

diameter-to-height ratio of subcritical core is 1 for minimization of the leakage of neutrons;

neutron source is isotropic point sources with $14 \mathrm{MeV}$ monoenergetic neutrons;

effective neutron multiplication factor is 0.97 ;

total number of source neutrons is 50,000 ;

number of batches is 500 .

The seven two-zone subcritical systems with different geometrical parameters were analyzed as well as the onezone subcritical system that was calculated for comparison. Every two-zone system has varied radius of the inner zone given ranging from 9.5 to $15.5 \mathrm{~cm}$. The radius of the outer zone was selected in such a way that $k_{\text {eff }}$ of all system is equal to 0.97 and in a way to provide a diameter-to-height ratio equal to 1 . Radioactive isotopes ${ }^{237} \mathrm{~Np}$ and ${ }^{243} \mathrm{Am}$ were chosen as the examples of nuclear waste for the investigation of transmutation characteristics. The volume normalized neutron flux integrated over space and energy (Flux), fission microscopic cross-section $\left(\sigma_{f}\right)$, capture microscopic cross-section $\left(\sigma_{c}\right)$ and ratio of these cross-sections $(\alpha)$ are used as main parameters in this work [5]. The fission microscopic cross-section $\left(\sigma_{f}\right)$ is the microscopic cross-section of fission reaction for the chosen isotopes $\left({ }^{237} \mathrm{~Np}\right.$ and $\left.{ }^{243} \mathrm{Am}\right)$ averaged by inner or outer zones. The capture microscopic cross-section $\left(\sigma_{c}\right)$ is the microscopic cross-section of capture reaction for the chosen isotopes $\left({ }^{237} \mathrm{~Np}\right.$ and $\left.{ }^{243} \mathrm{Am}\right)$ averaged by inner or outer zones. In addition, the value $(\alpha)$ is the ratio of the average capture to fission cross section for the chosen isotopes $\left({ }^{237} \mathrm{~Np}\right.$ and $\left.{ }^{243} \mathrm{Am}\right)$ in the inner or outer zones [5]. Finally, the value $(\alpha)$ is useful for un- derstanding transmutation potential of subcritical systems that are being analyzed. The optimal conditions of the two-zone subcritical system with respect to the transmutation efficiency (Flux and $\alpha$ ) were defined as the main goal for the present calculation results.

Figs. 9-22 represent the modelling results for homogeneous mixture of uranium metallic in the inner zone enriched to $20 \%$ and in the outer zone enriched to $4 \%$ for ${ }^{235} \mathrm{U}$. The data in the figures are laid out with the data on the ordinate and the radius of the inner zone in the abscissa, in the two-zone subcritical system. The certain square marker (point) on figures correspond to the one-zone subcritical system and they are represented in the figures for comparison.

First, we analyzed the change of the neutron flux in inner and outer zones (see Figs. 9 and 10) in case of changing the inner zone radius (and as the result, the volume of more enriched uranium).

Fig. 10 represents a natural increase for the neutron flux in outer zone in case of increasing the volume of inner zone due to increasing the amount of more enriched uranium $\left(20 \%\right.$ for $\left.{ }^{235} \mathrm{U}\right)$ in inner zone. And Fig. 9 shows the peak of the neutron flux with the radius of inner zone of approximately $14 \mathrm{~cm}$. This indicates that it is possible to choose the ratio of the volumes of both zones so that the neutron fluxes in inner and outer zones would be maximum and, as a result, the number of neutrons that can be used for the transmutation of minor actinides would be higher.

Then we investigated the transmutation characteristics of inner and outer zones with respect to the chosen isotopes which belong to minor actinides: ${ }^{237} \mathrm{~Np}$ and ${ }^{243} \mathrm{Am}$. We attributed the fission microscopic cross section, as the cross section of the most important process

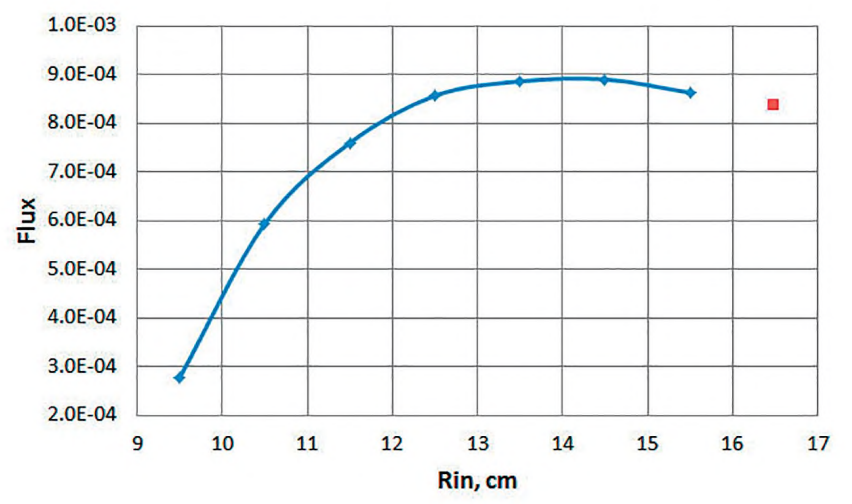

Fig. 9. The volume normalized neutron flux integrated over space and energy for inner zone 


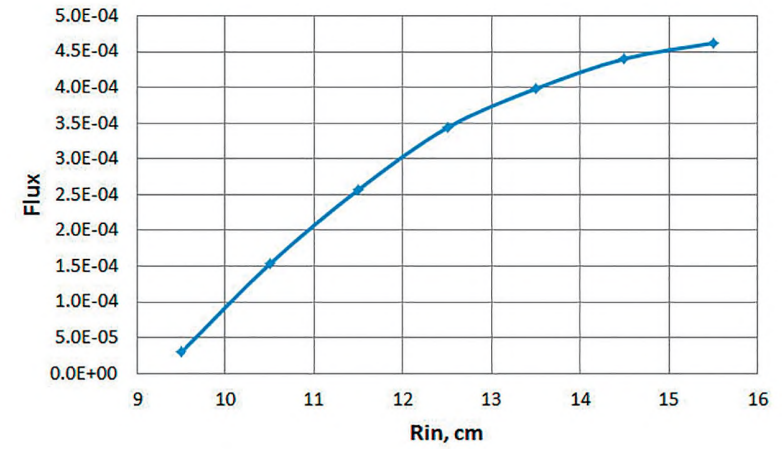

Fig. 10. The volume normalized neutron flux integrated over space and energy for outer zone

for the transmutation of minor actinides, to the transmutation characteristics. The capture microscopic cross section is important since the capture reaction plays the role of a competing process with respect to fission and significantly affects the "economy" of neutrons. The ratio of these two cross sections is an excellent indicator of the transmutation potential of the reactor; it was proposed by Massimo Salvatores in [5].

Microscopic cross sections of fission and capture in inner zone for ${ }^{237} \mathrm{~Np}$ and ${ }^{243} \mathrm{Am}$ are presented in Figs. 11-14. In case of increasing the volume of inner zone with more enriched uranium, the possibility of fission naturally increases for both isotopes. For capture cross section it is possible to choose the optimal volume ratio of both zones at which the probability of a capture reaction will be minimal. For both isotopes, the optimal volume ratio of inner and outer zones occurs when the radius of inner zone is approximately $13 \mathrm{~cm}$.

Figs. 15-18 show fission and capture microscopic cross sections in outer zone for ${ }^{237} \mathrm{~Np}$ and ${ }^{243} \mathrm{Am}$. The fission and capture cross sections for outer zone increase in case of increasing the volume of inner zone. As a result, a change in the geometric parameters of outer zone does not allow optimizing the transmutation characteristics of the two-zone subcritical system.

Figs. 19-22 show the ratios of capture and fission microscopic cross sections in inner and outer zones for ${ }^{237} \mathrm{~Np}$ and ${ }^{243} \mathrm{Am}$. Figures 19 and 20 show that it is possible to choose such a ratio of the volumes of inner and outer zones at which the probability of transmutation for both ${ }^{237} \mathrm{~Np}$ and ${ }^{243} \mathrm{Am}$ will be maximum. This optimal volume ratio is observed when the radius of inner zone is approximately $13-14 \mathrm{~cm}$ for both isotopes. For outer zone, it is slightly different (Figs. 21 and 22), here in case of decreasing the volume of outer zone, the probability of transmutation of the chosen isotopes will decrease. But at the same time, with optimal radii for inner zone, it is possible to

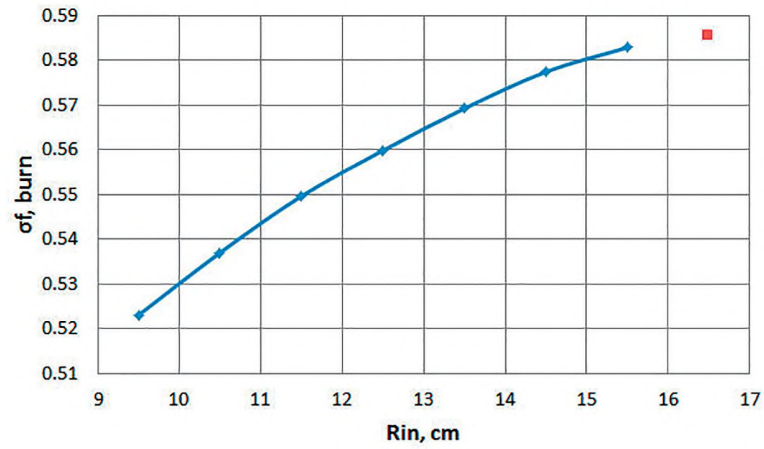

Fig. 11. The fission microscopic cross-section of ${ }^{237} \mathrm{~Np}$ for inner zone

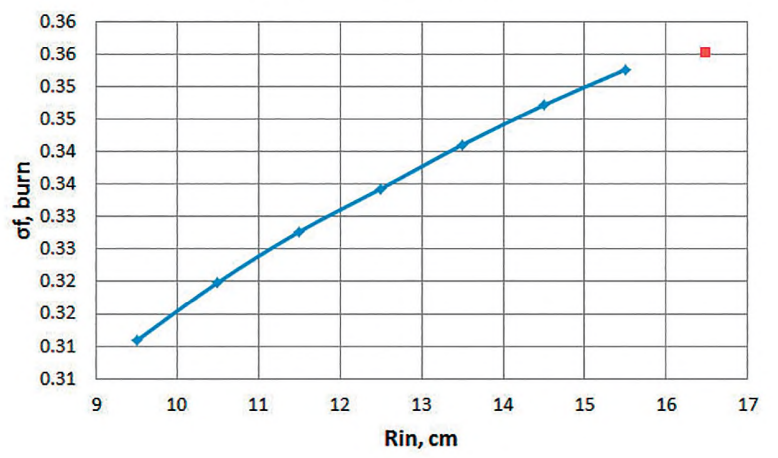

Fig. 12. The fission microscopic cross-section of ${ }^{243} \mathrm{Am}$ for inner zone

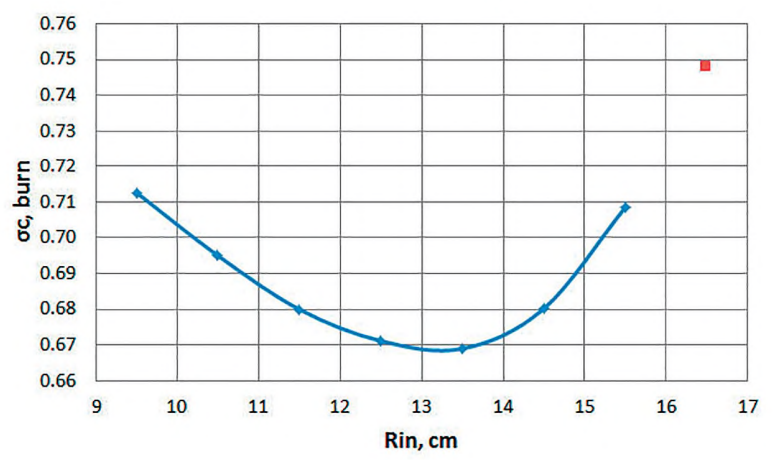

Fig. 13. The capture microscopic cross-section of ${ }^{237} \mathrm{~Np}$ for inner zone

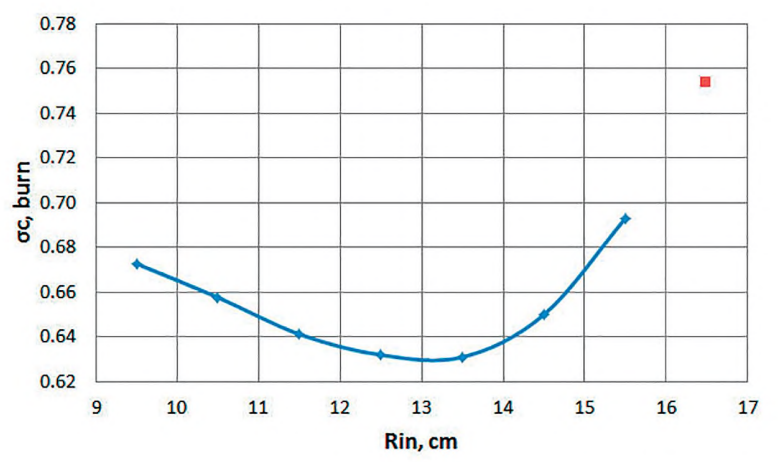

Fig. 14. The capture microscopic cross-section of ${ }^{243} \mathrm{Am}$ for inner zone 


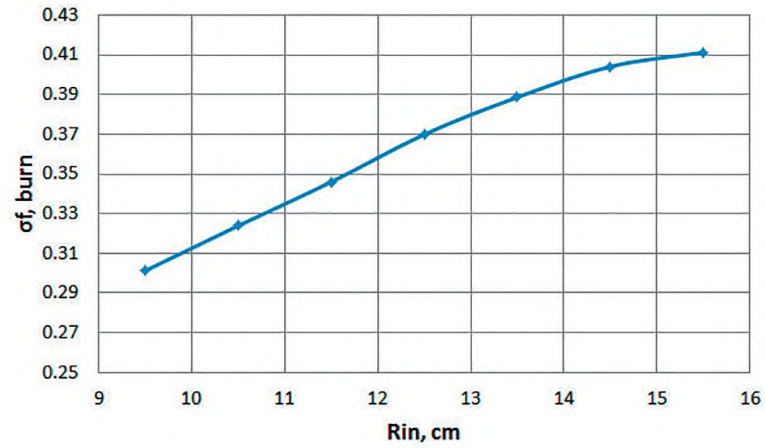

Fig. 15. The fission microscopic cross-section of ${ }^{237} \mathrm{~Np}$ for outer zone

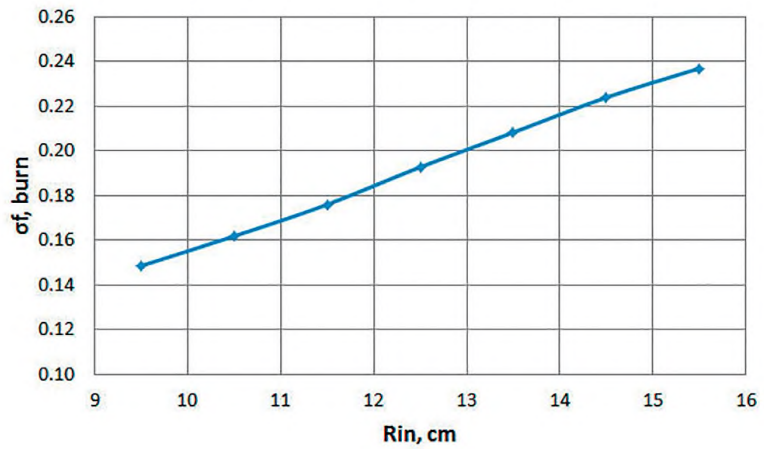

Fig. 16. The fission microscopic cross-section of ${ }^{243} \mathrm{Am}$ for outer zone

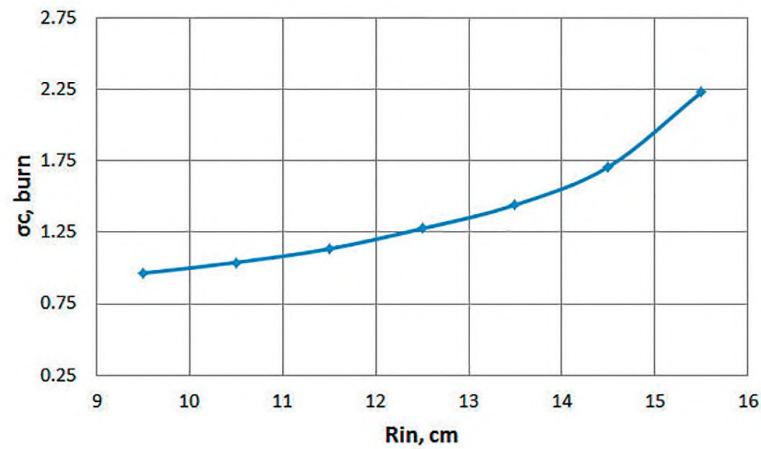

Fig. 17. The capture microscopic cross-section of ${ }^{237} \mathrm{~Np}$ for outer zone

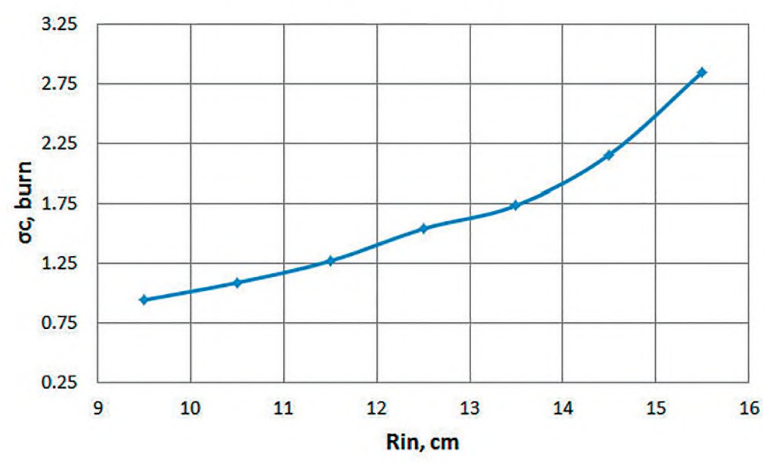

Fig. 18. The capture microscopic cross-section of ${ }^{243} \mathrm{Am}$ for outer zone

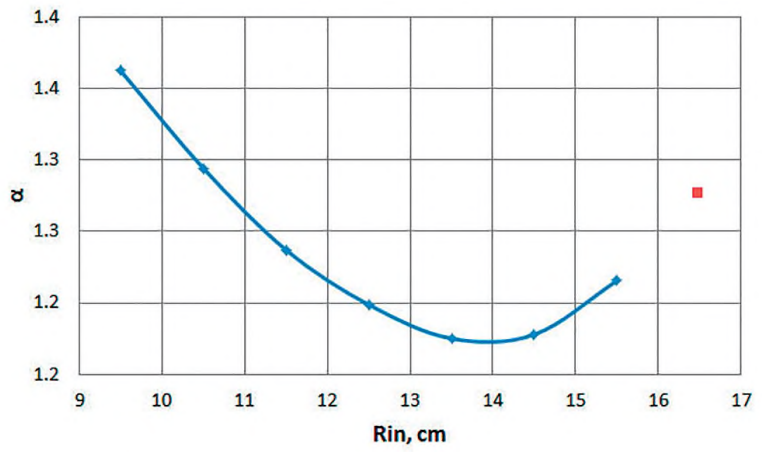

Fig. 19. The ratio of the average capture to fission cross section of ${ }^{237} \mathrm{~Np}$ in the inner zone

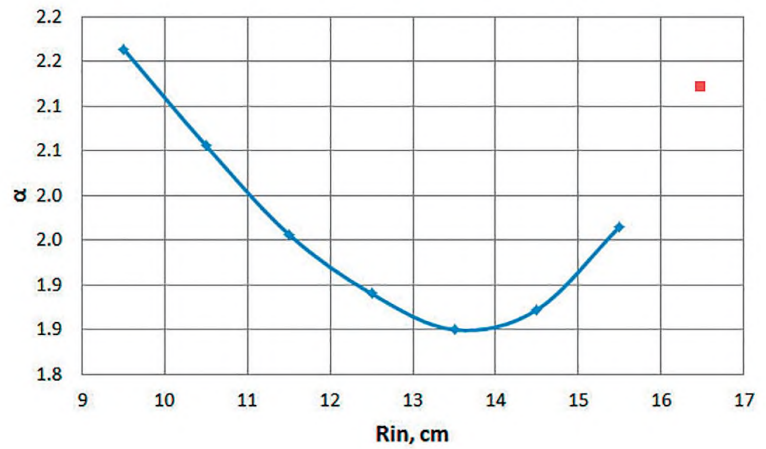

Fig. 20. The ratio of the average capture to fission cross section of ${ }^{243} \mathrm{Am}$ in the inner zone

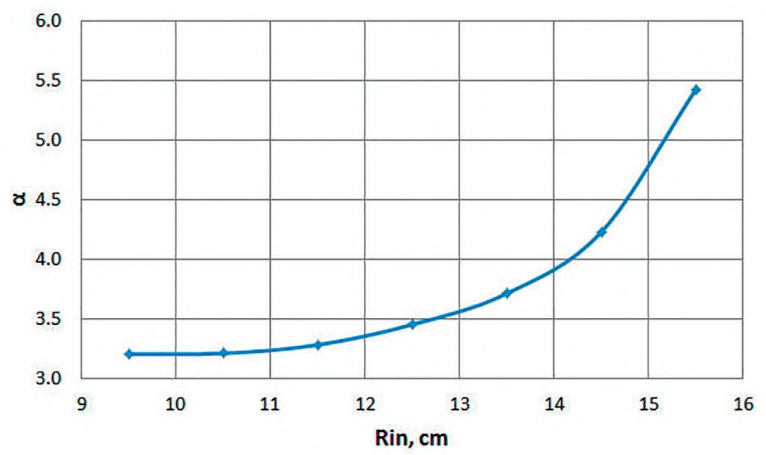

Fig. 21. The ratio of the average capture to fission cross section of ${ }^{237} \mathrm{~Np}$ in the outer zone

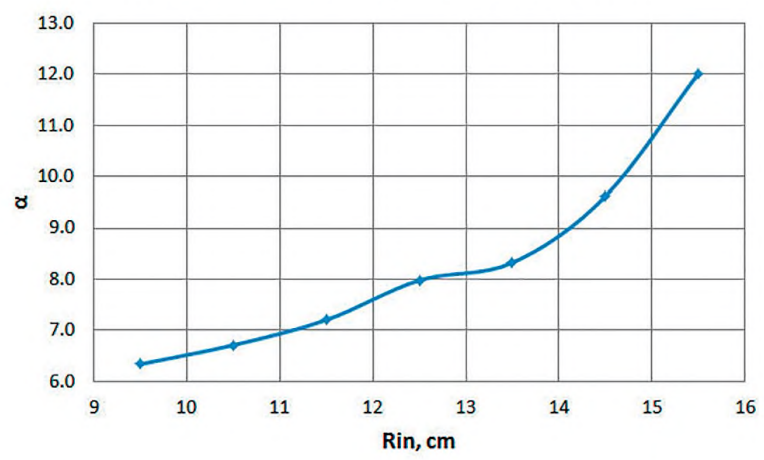

Fig. 22. The ratio of the average capture to fission cross section of ${ }^{243} \mathrm{Am}$ in the outer zone 
maintain acceptable values of the ratios of capture and fission microscopic cross sections for outer zone.

The presented modelling results show that even a simple distribution of materials with different nuclear properties (different enrichment for ${ }^{235} \mathrm{U}$ ) in the core can have an effect on the transmutation characteristics of the system. In this case, it is possible to choose the ratios of the volumes of different materials in such a way that these characteristics are optimal. Also, such a distribution of different materials may, if necessary, reduce the cost of a subcritical reactor due to a more efficient arrangement of highly enriched uranium. The presented example of division into subzones with different materials can be applied in the internal "fast" zone of the subcritical reactor shown in Fig. 2.

The Figs. 10, 14, 15, 20 and 21 display the optimal fuel composition for two-zone subcritical reactor from a viewpoint of transmutation efficiency for minor actinides. The optimization research presented in our previous publication [32] showed that the optimal fuel composition could be obtained for two-zone subcritical reactor from fuel cost perspective. The presented calculation results for two-zone homogeneous subcritical system without coolant and cladding materials could be a good basis for the development of effective heterogeneous model for future research in subcritical reactor systems.

\section{The energy-release calculations for two-zone subcritical system}

If we return to the model of a reactor with separate zones with fast and thermal neutron spectra, then it is of interest to consider the distribution of energy-release in the active core composed of two zones with different neutron spectra.

The energy-release calculations for two-zone subcritical system described in Chapter 2.2 were estimated with the help of the developed MCNP model. The total energy-release within the entire subcritical system was found to be $412.67 \mathrm{~kW}$ (for intensity of neutron generator = $1 \cdot 10^{13}$ neutron/s), while the energy-release in inner zone was found to be $70.85 \mathrm{~kW}$ and the energy-release in outer zone was $341.82 \mathrm{~kW}$. The energy-release $(Q)$ for each pin located on $\mathrm{x}$ axis from the target to the beryllium reflector (see Figs. 3-6) is presented in Fig. 9. The energy-release $(Q)$ in subcritical reactor was calculated with taking into account total neutron fissions in the core, averaged energy release from fission (about $200 \mathrm{MeV}$ ) and intensity of neutron generator (in this case $=1 \cdot 10^{13}$ neutron $/ \mathrm{s}$ ).

From Fig. 23 we can identify which pin's layer has the maximum and minimum of energy-release. It is clear that pins in outer zone possess higher energy-release due to thermal neutron spectrum. In addition, it can also be noted that the thermal neutron spectrum has influence on inner zone where pins 13 and 14 have higher energy-release compared with the other pins in inner zone.

From Fig. 23 we can see that the average energy-release, and as a result, the fuel burn-up in outer ("thermal") zone is about five times higher than the average energy-release in inner ("fast") zone. This may conduct additional difficulties in the operation of the future two-zone subcritical reactor.

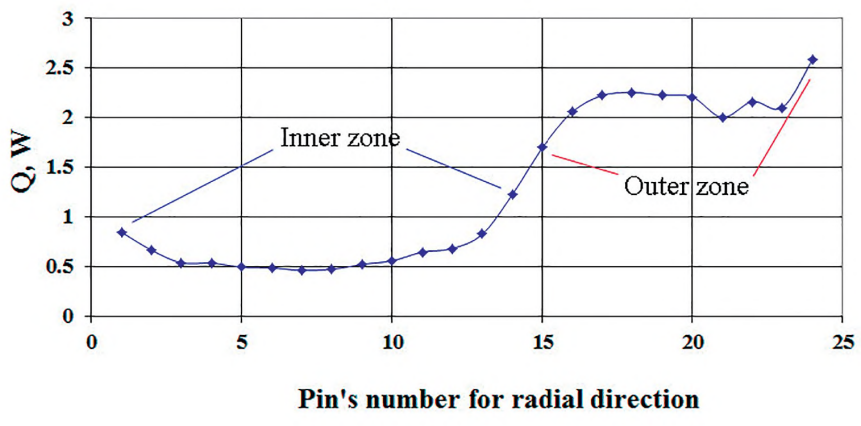

Fig. 23. The energy-release for individual pin located on $\mathrm{x}$ axis for radial direction versus the pin's number

\section{Conclusions}

This paper presents the idea behind the development of the two-zone subcritical research reactor driven by high-intensity neutron generator for investigation of nuclear waste transmutation along with the methodology and results of the performed simulations by various Monte Carlo codes.

The neutron-physical model of the presented subcritical reactor with the help of MCNP and Serpent Monte Carlo codes was developed and the energy-release calculations with the help of MCNP model were carried out.

The microscopic fission cross-section, microscopic capture cross-section and ratio of these cross-sections for ${ }^{237} \mathrm{~Np}$ and ${ }^{243} \mathrm{Am}$ were estimated for the developed model. It was found that there is an optimal value of ratio of inner zone volume to outer zone volume from the viewpoint of transmutation efficiency for minor actinides.

This research was carried out with the financial support of the State Projects of the National Academy of Sciences of Ukraine "Study of nonlinear and stochastic properties of multiplying nuclear systems" (State number: 0111U001944) and "The neutron distribution and 
the investigations of neutron-physical behavior for different types of nuclear reactors" (State number: 0106U005599). We acknowledge support from State Project of the National Academy of Sciences of Ukraine for young scientists "The investigation of optimal geometric and material characteristics for two-zone subcritical reactor driven by external neutron source" (State number: 0111U007144). This research was carried out with the financial support of the IAEA Coordinated Research Project (CRP) "Accelerator Driven Systems (ADS) Applications and use of Low-Enriched Uranium in ADS (T33002)" within the project 'The Two-Zone Subcritical Systems with Fast and Thermal Neutron Spectra for Transmutation of Minor Actinides and Long-Lived Fission Products'.

\section{References}

1. IAEA-TECDOC-985. Accelerator Driven Systems: Energy Generation and Transmutation of Nuclear Waste. Status report. Vienna: IAEA, 1997, $482 \mathrm{p}$.

2. A European Roadmap for Developing Accelerator Driven Systems (ADS) for Nuclear Waste Incineration. The European Technical Working Group on ADS, 2001, 145 p.

3. Salvatores M. (2006) Fuel Cycle Strategies for the Sustainable Development of Nuclear Energy: The Role of Accelerator Driven Systems. Nuclear Instruments and Methods in Physics Research A, vol. 562, pp. 578-584.

4. Taczanowski S. (2003) Transmutations of Nuclear Waste in Accelerator-Driven Subcritical Systems. Applied Energy, vol. 75, pp. 97-117.

5. Salvatores M. (2002) The Physics of Transmutation in Critical or Subcritical Reactors. C. R. Physique, vol. 3, pp. 999-1012.

6. Salvatores M. (2002) Transmutation: Issues, Innovative Options and Perspectives. Progress in Nuclear Energy, vol. 40, pp. 375-402.

7. Yang W. S., Kim Y., Hill R. N., Taiwo T. A., Khalil H. S. (2004) Long-Lived Fission Product Transmutation Studies. Nuclear Science and Engineering, vol. 146, pp. 291-318.

8. Jongen Y. et al. (2002) High-Intensity Cyclotrons for Radioisotope Production and Accelerator Driven Systems. Nuclear Physics, vol. 701, pp. 100-103. doi: 10.1016/S03759474(01)01555-X.

9. Abderrahim H., Baeten P., Bruyn D., Fernandez R. (2012) MYRRHA - A Multi-Purpose Fast Spectrum Research Reactor. Energy Conversion and Management, vol. 63, pp. 4-10. https://doi.org/10.1016/j.enconman.2012.02.025.

10. Gohar Y. et al. (2006) Accelerator-Driven Subcritical Facility: Conceptual Design Development. Nuclear Instruments and Methods in Physics Research A, vol. 562, pp. 870-874.

11. Zhong Z., Gohar Y., Talamo A. (2011) Analysis of Fuel Management in the KIPT Neutron Source Facility. Annals of Nuclear Energy, vol. 5, pp. 1014-1022.
12. Verbeke J. M., Leung K. N., Vujic J. (2000) Development of a Sealed-Accelerator-Tube Neutron Generator. Applied Radiation and Isotopes, vol. 53, pp. 801-809.

13. Markovskij D. V. et al. (2001) Experimental Activation Study of Some Russian Vanadium Alloys with $14-\mathrm{MeV}$ Neutrons at SNEG-13 Facility. Fusion Engineering and Design, vol. 58-59, pp. 591-594.

14. Sadowski M. J., Scholz M. (2003) Comments on Status of Plasma Focus Research. Proc. Int. Workshop "Dense Magnetized Plasmas" (Warsaw, Poland, November 25-26, 2003).

15. Talamo A., Gohar Y., Sadovich S., Kiyavitskaya H., Bournos V., Fokov Y., Routkovskaya C. (2014) High enriched to low enriched fuel conversion in YALINA Booster facility. Progress in Nuclear Energy, vol. 70, pp. 43-53.

16. Stacey W. M. (2001) Capabilities of a DT Tokamak Fusion Neutron Source for Driving a Spent Nuclear Fuel Transmutation Reactor. Nuclear Fusion, vol. 41, pp. $135-154$.

17. Daniel H., Petrov Yu. V. (1996) Subcritical Fission Reactor Driven by the Low Power Accelerator. Nuclear Instruments and Methods in Physics Research A, vol. 373, pp. 31-134.

18. Kolomiec N. F. (1985) Investigation and Development of Metal-Tritium Neutron-Produced Targets for Accelerators of charged particles (Ph.D. thesis). Kyiv, Institute for Nuclear Research, $156 \mathrm{p}$.

19. Gulik V. I. (2012) The Model of Two-zone Research Subcritical Nuclear Reactor driven by High-Intensity Neutron Generator (Ph.D. thesis). Kyiv, Institute for Nuclear Research, $143 \mathrm{p}$.

20. Babenko V. A., Gulik V. I., Jenkovszky L. L., et al. (2005) Study of One-zone Subcritical Amplifier of Neutron Flux Involving Enriched Uranium. Problems of Atomic Science and Technology, vol. 45, no. 6, pp. 122-126.

21. Babenko V.A., Gulik V. I., Jenkovszky L. L., Pavlovych V.M., Pupirina E. A. (2006) On the Subcritical Amplifier of Neutron Flux Based on Enriched Uranium. In: Čechák T., Jenkovszky L., Karpenko I. (eds.) Nuclear Science and Safety in Europe. Springer Heidelberg, pp. 253-263. doi: 10.1007/978-1-4020-4965-1_21.

22. Gulik V. I., Pavlovich V. N., Pupirina E. A., Babenko V. A. (2006) The Research Subcritical Reactor. Proc. Int. Conf. "Research Reactors in $21^{\text {st }}$ century" (Moscow, Russia, June 20-23, 2006).

23. Briesmeister J. MCNP-A General Monte Carlo Code $N$-Particle Transport Code Version 4A, LA-12625. Los Alamos National Laboratory, 1993.

24. Babenko V. O., Gulik V. I., Pavlovych V. M., Pupirina O. M. (2006) Two-zone subcritical nuclear reactors. Problems of Nuclear Power Plants' Safety and of Chornobyl, vol. 6, pp. $8-15$.

25. Babenko V. O., Gulik V. I., Pavlovych V. M. (2008) The Research Subcritical Reactor. Nuclear Physics and Atomic Energy, vol. 9, no. 1, pp. 56-61.

26. Babenko V. O., Gulik V. I., Pavlovych V. M. (2010) The New 
The Development of Neutron-Physical Model

Research Subcritical Reactor driven by a High-intensity Neutron Generator for Transmutation of the Nuclear Waste. Proc. Int. Conf. "WM2010" (Phoenix, Arizona, US, 7-11 March, 2010).

27. Babenko V. O., Gulik V. I., Pavlovych V. M. (2012) Modeling of Two-zone Accelerator-Driven Systems. Nuclear Physics and Atomic Energy, vol. 13, no. 3, pp. 266-275.

28. Babenko V. O., Gulik V. I., Pavlovych V. M., Rybalova A. P. (2011) About Possibility of Nuclear Waste Transmutation in Subcritical System Driven by High-Intensity Neutron Generator. Problems of Nuclear Power Plants' Safety and of Chornobyl, vol. 16, pp. 8-16.

29. Babenko V. O., Gulik V. I., Pavlovych V. M. (2012) The Transmutation of Nuclear Waste in the Two-Zone Subcritical System Driven by High-Intensity Neutron Generator. Proc. Int. Conf. "WM2012" (Phoenix, Arizona, US, February 26-March 1, 2012).

30. Leppänen J., Pusa M., Viitanen T., Valtavirta V., Kaltiaisenaho T. (2015) The Serpent Monte Carlo code: Status, development and applications in 2013. Annals of Nuclear Energy, vol. 82, pp. 142-150.

31. Gulik V., Tkaczyk A. H. (2013) Optimization of Geometry, Material and Economic Parameters of a TwoZone Subcritical Reactor for Transmutation of Nuclear Waste with SERPENT Monte Carlo Code. Proc. Int. Conf. Supercomputing in Nuclear Applications \& Monte Carlo (SNA\&MC2013) (Paris, France, October 27-31, 2013).

32. Gulik V., Tkaczyk A. H. (2014) Cost Optimization of ADS Design: Comparative Study of Externally Driven Heterogeneous and Homogeneous Two-Zone Subcritical Reactor Systems. Nuclear Engineering and Design, vol. 270, pp. 133-142.

\section{В. І. Гулік ${ }^{1}$, В. М. Павлович ${ }^{2}$ \\ ${ }^{1}$ Iнститут проблем безпеки АЕС НАН украйни, вул. Лисогірська, 12, м. Київ, 03028, Украӥна ${ }^{2}$ Інститут ядерних досліджень НАН Украйни, nросп. Науки, 47, м. Київ, 03680, Україна}

\section{Розробка нейтронно-фізичної моделі двозонного дослідницького підкритичного реактора для трансмутації ядерних відходів}

Створення невеликих дослідницьких підкритичних реакторів необхідно, зокрема, для розробки технології трансмутаціі ядерних відходів у підкритичних системах, що керуються зовнішнім джерелом нейтронів. Будівництво таких установок дає змогу розробити технологію трансмутації ядерних відходів без будівництва дорогого промислового підкритичного реактора. Недорогий генератор нейтронів може служити зовнішнім джерелом нейтронів для таких дослідницьких підкритичних реакторів. У роботі запропоновано двозонну модель підкритичної системи, що керусться генератором нейтронів високої інтенсивності. Така система може використовувати дві окремі зони реактора з різними нейтронними спектрами: швидким та тепловим. Представлено основні етапи розробки запропонованої моделі двозонного підкритичного реактора. Результати моделювання виконано в кодах Serpent i MCNP з метою оптимізації геометрії і складу палива у двозонній підкритичній системі. Також представлено огляд різних установок, які можуть бути використані як зовнішнє джерело нейтронів для підкритичного реактора. Однак оптимальним джерелом нейтронів для недорогого дослідницького підкритичного реактора для дослідження трансмутаціі ядерних відходів був обраний D-T генератор нейтронів високої інтенсивності. У цілому спостерігасться, що двозонна підкритична система може ефективно посилювати потік нейтронів від зовнішніх джерел нейтронів.

Ключові слова: підкритичні системи, що керуються прискорювачами, підкритичний реактор, трансмутація радіоактивних відходів, оптимізація підкритичної зони.

\section{В. И. Гулик ${ }^{1}$, В. Н. Павлович ${ }^{2}$}

${ }^{1}$ Институт проблем безопасности АЭС НАН Украинь, ул. Льсогорская, 12, г. Киев, 03028, Украина

${ }^{2}$ Институт ядерных исследований НАН Украинь, nросп. Науки, 47, г. Киев, 03680, Украина

\section{Разработка нейтронно-физической модели двухзонного исследовательского подкритического реактора для трансмутации ядерных отходов}

Создание небольших исследовательских подкритических реакторов необходимо, в частности, для разработки технологии трансмутации ядерных отходов в подкритических системах, управляемых внешними источниками нейтронов. Строительство таких установок позволит разработать технологию трансмутации ядерных отходов без строительства дорогостоящего промышленного подкритического реактора. Недорогой генератор нейтронов может служить внешним источником нейтронов для таких исследовательских подкритических реакторов. В данной работе предложена двухзонная модель подкритической системы, которая управляется генератором нейтронов 
высокой интенсивности. Данная система может использовать две отдельные зоны реактора с разными нейтронными спектрами: быстрым и тепловым. Представлены основные этапы развития предлагаемой модели двухзонного подкритического реактора. Результаты моделирования выполнены в кодах Serpent и MCNP с целью оптимизации геометрии и состава топлива двухзонной подкритической системы. Представлен обзор анализа различных установок, которые могут быть использованы в качестве внешнего источника нейтронов для подкритического реактора. Однако в качестве оптимального источника нейтронов для недорогого исследовательского подкритического реактора для исследования трансмутации ядерных отходов был выбран D-T генератор нейтронов высокой интенсивности. В целом показано, что двухзонная подкритическая система может эффективно усиливать поток нейтронов от внешних источников нейтронов.

Ключевые слова: подкритические системы, управляемые ускорителями; подкритический реактор; трансмутация радиоактивных отходов; оптимизация подкритической зоны.

Надійшла 24.01.2019

Received 24.01.2019 